\title{
East African Regional Integration: Challenges in Meeting the Convergence Criteria for Monetary Union: A Survey
}

\author{
Annette Kuteesa \\ Correspondence: Annette Kuteesa, Economic Policy Research Centre, P.O. Box 7841, Kampala, Uganda. Tel: \\ 256-4-145-4103. E-mail: akuteesa@eprc.or.ug
}

Received: July 22, $2012 \quad$ Accepted: August 21, $2012 \quad$ Online Published: September 1, 2012

doi:10.5539/ijef.v4n10p147 URL: http://dx.doi.org/10.5539/ijef.v4n10p147

\begin{abstract}
The realization of a successful monetary union among EAC partner states depends upon a sufficient degree of convergence of partners economies to established criteria. Gathering but scattered research has begun assessing the various benchmarks for this characteristic. This work integrates and synthesizes the various findings of literature with the view of providing a general perspective on how far the partner states have reached in meeting the macroeconomic convergence criteria and whether they have met the precondition for ascending the union. The review is done with anticipation of uncovering the challenges countries are encountering in aligning the economies to set criteria and what possible policy strategies exist to overcome these problems. Findings reveal that there has been very limited convergence. Generally countries remain behind the staged indictors. Progress to the monetary union is challenged by the highly demanding criteria, lack of exchange rate mechanism, obstacles to the common market, multiple memberships and many more. While countries might have the option of revising the benchmarks, efforts to strengthen national economic growth, build regional capacities, harmonize policies related to the monetary union, and correct constraints in the common market will enhance deeper integration and contribute greatly to macro-economic convergence.
\end{abstract}

Keywords: EAC partner states, macroeconomic convergence, challenges, policies

\section{Introduction}

The East African Community (EAC) re-emerged in 2000 after the ratification of the EAC treaty signed earlier in 1999 by member states of Kenya Uganda and Tanzania. Rwanda and Burundi joined the union in 2007. As by the treaty, the objectives of the EAC are to develop policies and programs aimed at widening and deepening co-operation among the Partner States in economic, social, cultural and political fields their mutual benefit. Within this framework partner countries also resolved to establish amongst themselves a customs union, a common market, subsequently a monetary union and ultimately a political federation to strengthen, regulate, and enhance an accelerated harmonious, equitable and sustained economic development (EAC, 2007). This collaboration of efforts has so far yielded a customs union launched in 2005 and the common market established in 2010 .

At a glance the EAC common market covers a geographical area 1.82 million square kilo meters (Note 1) and a growing population of 133.1 million persons. The economic community displays some improvements in economic growth despite country level differences in economic performance. Market price GDP which stood at 74.5 billion USD accordingly in 2005 registered 79.2 billion USD in 2010. Individual country contributions are shown in figure 1. 


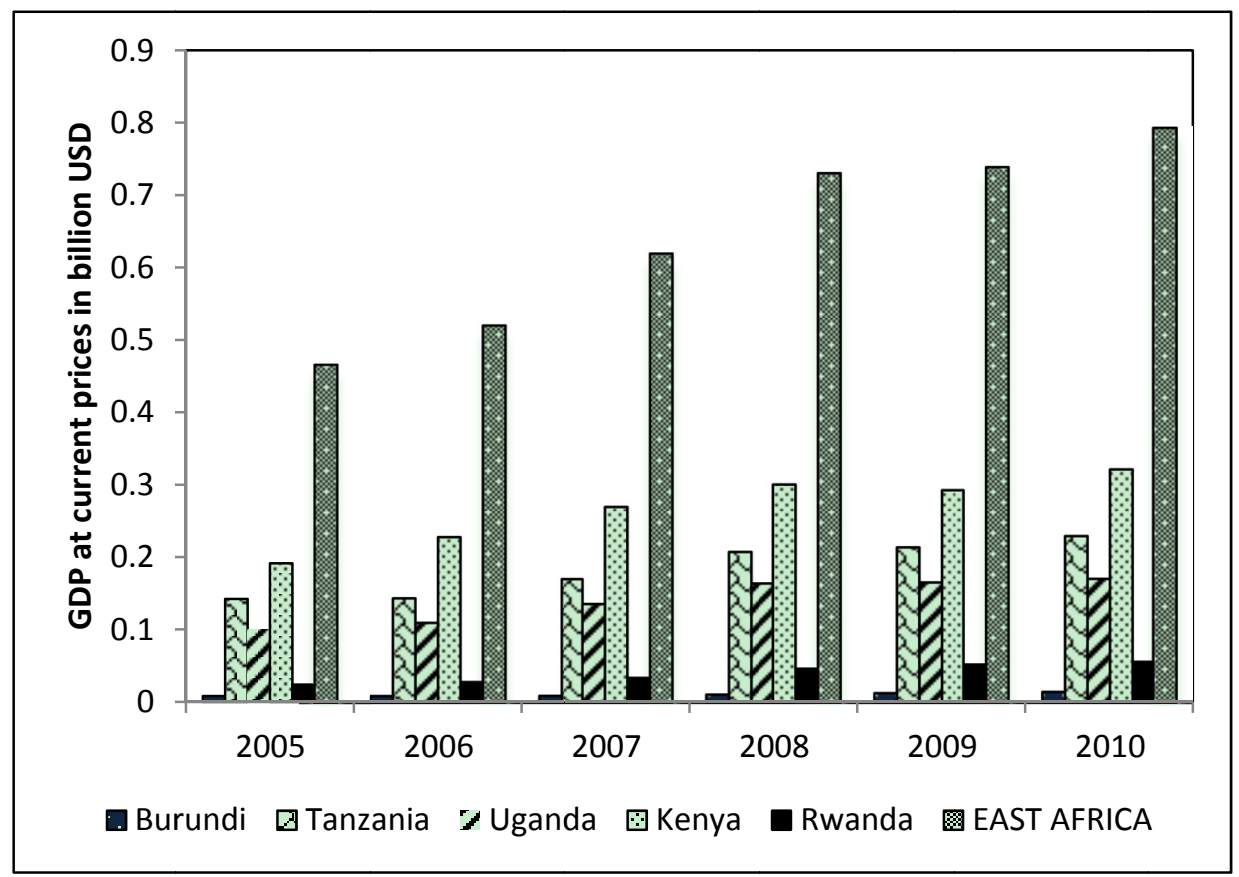

Figure 1. Regional trends in GDP at current prices

Source EAC secretariat, 2011

Kenya and Tanzania that have always had stronger economies compared to other countries in the REC accounted for most these gains. There are also signs of recovery in growth of Real GDP whose rate fell tremendously $4.4 \%$ in 2009 after global economic crisis of 2008. In 2010 the rate registered 5.9\%. Further improvements have occurred in standard of wellbeing across the region with overall per capita GDP at current price rising from $\$ 632$ in 2009 to $\$ 685$ in 2010 respectively. How individual nations have fared in the past six years in wellbeing is illustrated in figure 2. The integration has also boosted the volume of intra trade among member countries. Kenya remains the main source of imports for all other countries in the block although its self receives a small amount of imports from them. But like all other countries it's overall trade position remains weak with a widening trade balance reflecting that imports continue to surpass exports.

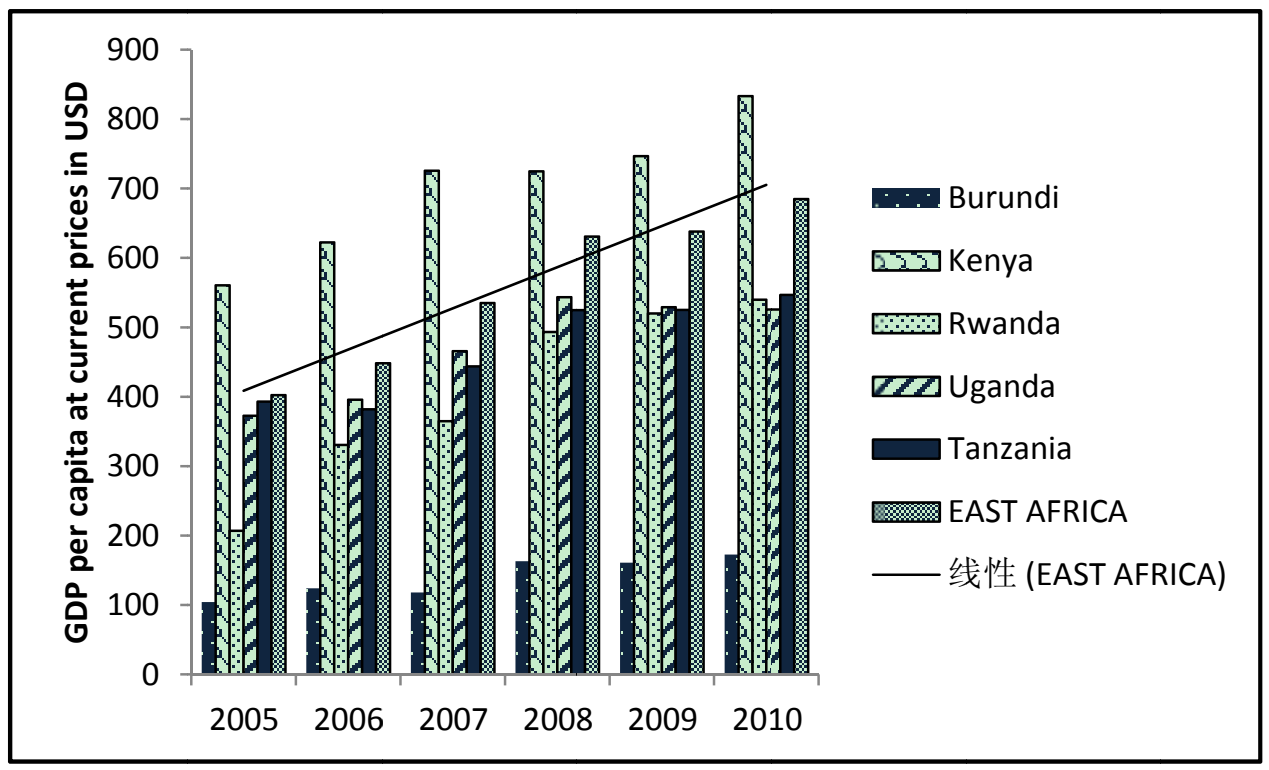

Figure 2. Level of GDP per capita for EAC from 2005-2010

Source: EAC secretariat, 2011 
Recent developments in negotiations have sought to elevate the REC to a monetary union (MU) with the introduction of the single currency by 2015 (EAC, 2009). Granted, the benefits of a single currency area several including reductions in transaction costs associated with cross border trade and volatility of exchange rates across the union thus facilitating trade and investment in the region. The union can also aid in the strengthening of the common market due to the unrestricted movement of goods and services, human resource and capital thus enhance efficiency in production leading to increased GDP. Further benefits can be derived in terms of price stability and convergence which could reduce on market discrimination, foster competition and increase economic efficiency (Alessina and Barro, 2002; Mundell, 1961; Mckinnon, 1963; Flemming, 1971). For the case of EAC, the MU is sought to facilitate the formation of stable political state. However, there are also costs linked to the unification, the major being loss of national autonomy in monetary policy. Other costs are tied to the possibility of increased inflation and unemployment, loss of exchange policy and fiscal independence (Schuberth and Wehinger, 1998; Bean, 1992; Calmfors, 2001). The magnitude of this loss depends on how well individual countries were conducting monetary policy prior to joining the currency union. But in order to reap the maximum benefits and minimize costs there ought to be a sufficient degree of macro-economic convergence, and financial integration among aspiring economies preceding the fusion. Without this compatibility, partner countries risk of high adjustment costs at the start of the EAMU and an unstable union.

Consistent with a number of RECs elsewhere, EAC countries have put in place macro convergence criteria to guide and hasten the merger. But how far the nations have progressed in aligning their economies to the set bench marks still troubles many given the discrepancies in institutional mechanisms, social and economic structures. Well as the community has made substantial gains in the process ahead of the union by establishing relevant committees overseeing coordination and harmonization of policies; standardizing the value added tax rates; maintain ace of currency convertibility by all partner states; modernizing and integrating the payment systems and settlements; and synchronizing the trading practices and rules in stock market exchange (EAC, 2009), partner commitment has remained low with some policies registering 3 out of 5 participating countries. In addition, policy coordination has stayed largely in the hands of the state forcing macro-economic convergence to proceed in an environment that is prone to economic disruptions.

A small but growing amount of empirical research has begun to examine the subject. Works have investigated the degree of economic integration and the suitability to which EAC region constitutes a single currency. While most of these have applied laborious econometric techniques, others have been more consultative in nature rooted in ongoing regional tendencies. Rather than break new grounds through fresh research, this paper aims at integrating and synthesizing key findings of this scattered literature with the view of highlighting the major issues as the region moves towards the East African monetary union (EAMU). The intension is to provide a general perspective on how far the partner states have reached in meeting the macroeconomic convergence bench marks, the challenges they are encountering in aligning the economies to set criteria and the possible policy strategies to overcome them. While importance of various empirical techniques utilized by the scholars is recognized, discussion of methodological issues is reserved for a later time. A total of 12 studies are examined. The rest of this paper proceeds by first examining the status of member countries in fulfilling the criteria set by the EAC. This is followed by a discussion of perceived challenges and approaches through which they can be countered. The paper ends by presenting the conclusions and policy implications.

\section{Status of the Partner Economies in Fulfilling Macro Convergence Criteria}

\subsection{The EAC Macro-economic Convergence Criteria}

As mentioned earlier transiting to the EAMU is pegged on the achieving the macroeconomic convergence criteria established by the EAC monetary committee affairs (MAC, 2009). Generally the framework is rather comprehensive constituting of traditional criteria and their derivatives grouped into primary and secondary criteria that must be met and maintained at two separate stages before the introduction of the single currency in the third stage. Details of these key indicators and associated timings are provided in table 1. 
Table 1. EAC Macroeconomic Convergence Criteria

\begin{tabular}{|c|c|c|c|c|}
\hline & Criteria & $\begin{array}{c}\text { Stage I } \\
2007-2010\end{array}$ & $\begin{array}{c}\text { Stage II } \\
2011-2014\end{array}$ & $\begin{array}{c}\text { Stage III } \\
2015\end{array}$ \\
\hline \multicolumn{5}{|c|}{ Primary Criteria } \\
\hline- & Budget deficit/GDP (excluding grants) & $<6 \%$ & $<5 \%$ & \\
\hline- & Budget deficit/GDP (including grants) & $<3 \%$ & $<2 \%$ & \\
\hline- & External Reserves (months of imports of goods and non-factor services) & $>4$ & $>6$ & \\
\hline- & Annual Inflation rate & $<5 \%$ & $<5 \%$ & \\
\hline \multicolumn{5}{|c|}{ Secondary Criteria } \\
\hline- & Exchange rates & Stable & & \\
\hline- & Interest rates (Market based) & $\begin{array}{c}\text { Achieve and } \\
\text { Maintain }\end{array}$ & $\bullet$ & $\begin{array}{l}\text { Introduction } \\
\text { and circulation }\end{array}$ \\
\hline- & Real GDP growth rate & $>7 \%$ & $>7 \%$ & of a single East \\
\hline - & National savings/GDP & $>20 \%$ & $>20 \%$ & African \\
\hline- & Sustained pursuit of debt sustainability & $\bullet$ & $\bullet$ & Currency \\
\hline- & $\begin{array}{l}\text { Reduction of current account deficit (excluding grants) as a percentage } \\
\text { of GDP to sustainable level consistent with debt sustainability }\end{array}$ & $\bullet$ & $\bullet$ & \\
\hline - & $\begin{array}{l}\text { Implementation of } 25 \text { core principles of bank supervision and } \\
\text { regulation based on the agreed action plan for harmonization of bank } \\
\text { supervision }\end{array}$ & $\bullet$ & & \\
\hline- & $\begin{array}{l}\text { Adherence to core principles of systematically important payment } \\
\text { systems by modernizing payment and settlement systems }\end{array}$ & $\bullet$ & & \\
\hline
\end{tabular}

Note: Source of Information is the EAC Monetary Affairs Committee (MAC) report, 2009; $\bullet$ implies that the criterion is considered for that stage.

The context under which EAC's macroeconomic convergence criteria are established compares well with those followed by other regional economic communities e.g. the EU, SADC, COMESA, and UEMOA in that they all center on areas of price stability, exchange rate stability, strengthening the level external reserves, fiscal restraint (by limiting government debt and deficits) and encouraging policy coordination among partner states. Variations are in the broadness of criteria and flexibility of set targets. For example EAC benchmarks hardly allow for adjustments for economic shocks within set criteria. While other initiatives such as SADC allows for member countries' budget deficits to fluctuate between 3 or -1 of the prevailing regional average for over a 6 year period. In controlling fiscal debt, EAC's criteria remains open while other initiatives have set limits to debt borrowing and accumulation of about 60 to 70 percent (Note 2). In extensiveness of the criteria, EAC is most similar to COMESA.

All studies encountered under in this work have relied on one or more of these criteria when determining regional integration. Emphasis has been placed on both the changing patterns and equalization of criteria to set targets but also on their distribution, linkage and merger to a common point of movement or convergence; correspondingly findings are presented as per se.

\subsection{Emerging Macro-economic Trends and Criteria}

At the moment, all countries have gone through the first stage of convergence and are underway the second stage. While works have assessed trends as early as 2000, this discussion is limited of findings to only the stage I for purposes of giving a more meaningful interpretation to the criteria and also there is not much data for stage II. Generally the findings show that country performances have remained behind Stage I bench marks compromising on the future prospects of attaining the goals set in Stage II (IMF, 2011a, 2011b; ECB, 2010). In regards to the primary criteria, tendencies of budget deficits excluding grants indicate that Rwanda, Tanzania and Burundi have consistently have found it difficult to stay below the $6 \%$ target registering double digits as late as 2010. Kenya and Uganda have performed relatively well with former meeting the criteria until 2009 and thereafter defaulted on the benchmark possibly due to the economic downturn. 


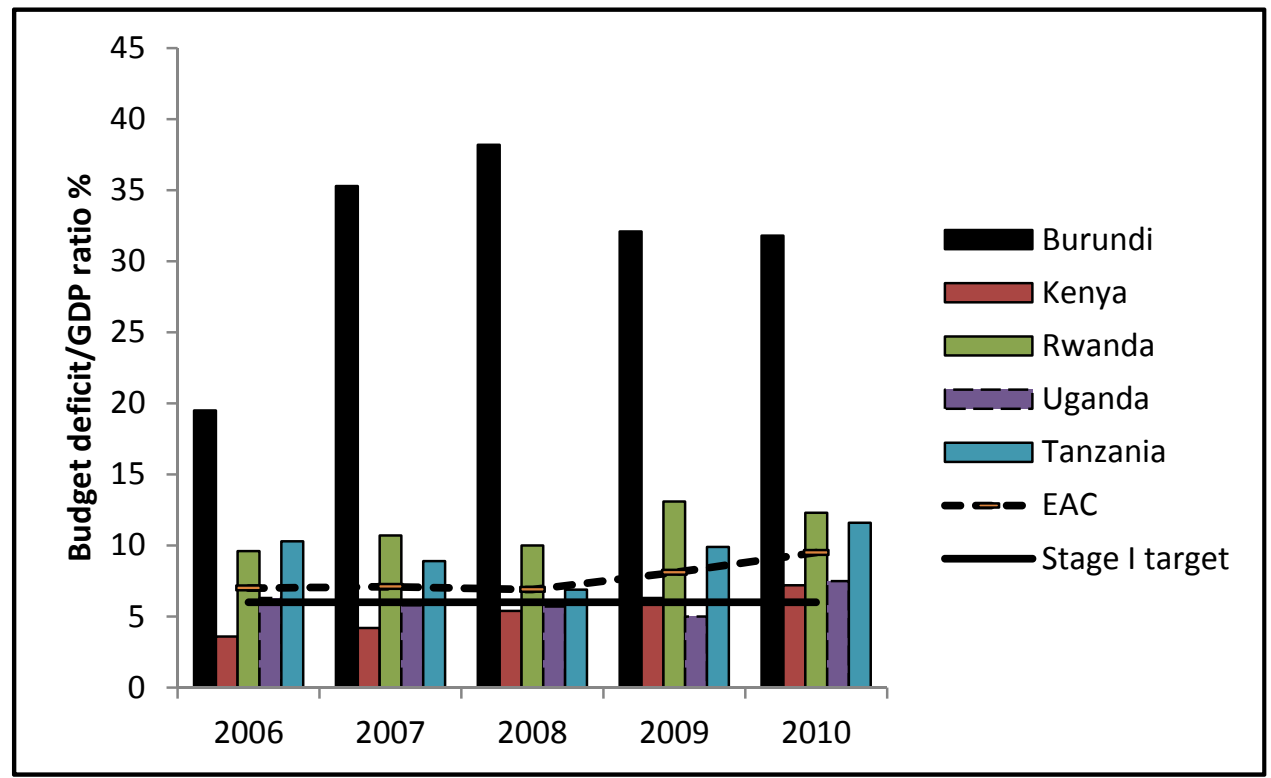

Figure 3. Trends in budget deficit to GDP ratio excluding grants for EAC countries for 2006-2010

Source: IMF African Department database and World Economic Outlook, 2011

As far as budget deficits including grants are concerned, most countries have progressed relatively well by remaining below the 3\% target. On combining the two findings, it becomes clear that the countries' capacity to generate their own revenue remains low compared to their financial demands. The high dependency on grants or aid for economic development is risky for any economy even more dangerous as nations ascend the union given that such donor support is seasonal. This is so most worrying for especially Burundi, Rwanda and Tanzania.

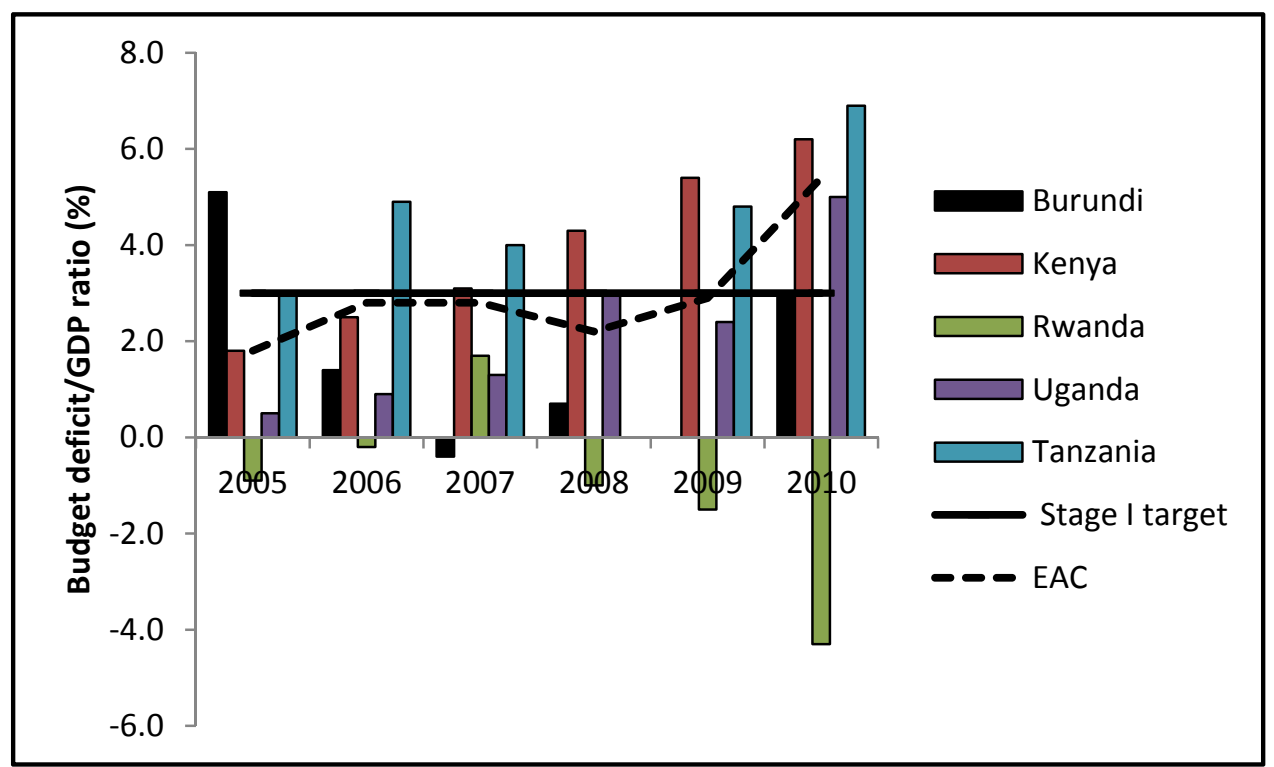

Figure 4. Trends in budget deficit to GDP ratio including grants for EAC countries for 2005-2010

Source: IMF African Department database and World Economic Outlook, 2011

Generally countries have fulfilled the requirement of 4 months of import cover for goods and services for external reserves except for Kenya which has underperformed in this regards. Burundi which also trailed behind in 2007 appears to have caught up to Rwanda, Uganda, and Tanzania. Overall Uganda has the strongest position as seen in figure 5. Generally countries did well until the economic downturn 2008-2009 at which point the 
deficits increased and reserves fell for the region. However the progress in controlling inflation at $5 \%$ target has been very slow. Countries continue to be above the 5\% target mark as shown in figure 6 . The high levels are blamed on high rise in food prices across the region especially from 2007 to 2009. Elevated and divergent rates don't favor exchange rate stability in that they create expectation about incompatibility of exchange rate in the region could further destabilize the union.

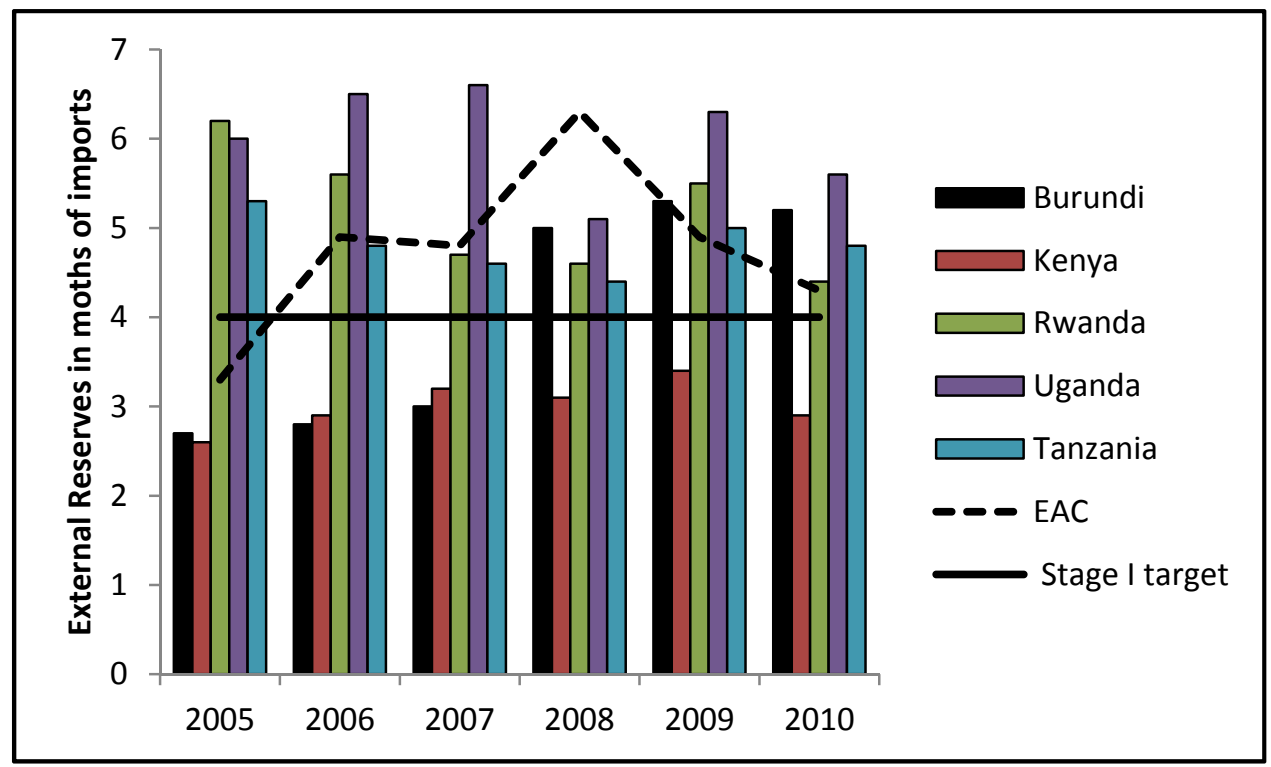

Figure 5. External Reserves in months of imports of goods and services for EAC countries 2005-2010 Source: IMF African Department database and World Economic Outlook, 2011

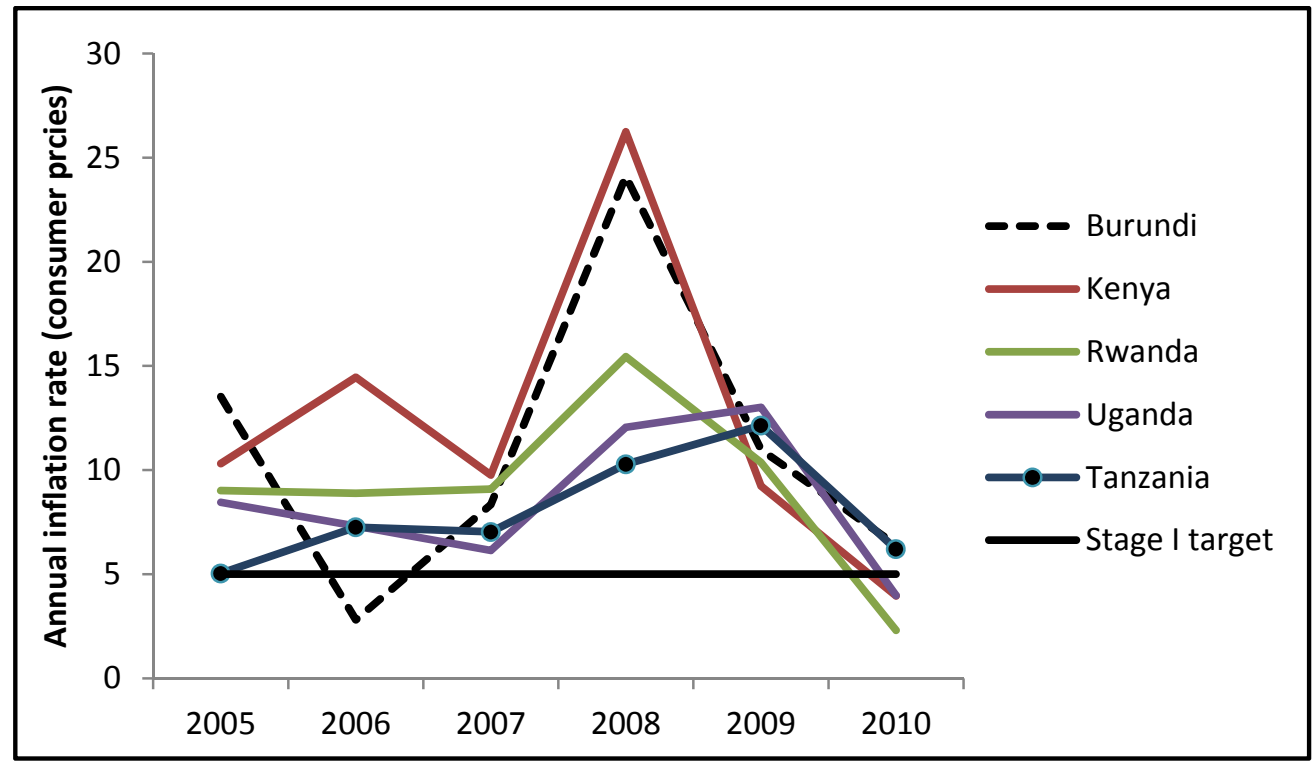

Figure 6. Annual Inflation rate at consumer prices (\%) of EAC states 2005-2010

Source: World Bank WDI, 2012

On meeting the secondary criteria, tendencies of bilateral exchange rates (ER) and interest rates in the region would offer the best indication of economic integration. A significant achievement by EAC economies has the maintenance of market based interest and exchange rates. Another achievement has been the currency convertibility where by local currencies are changed to a foreign currency such as dollar, Euro, pound sterling and as wells other regional currencies. In assessing stability and convergence of bilateral exchange rates studies 
have expressed concerns due to a lack of exchange rate mechanism between countries. The investigation by ECB (2010) determining ER stability revealed a depreciation of the all other currencies against the Kenyan shilling. However the Ugandan currency was found to be more stable against the Kenyan currency compared to other currencies. Countries have also exhibited differing interest in last decade as depicted in figure in figure 7.

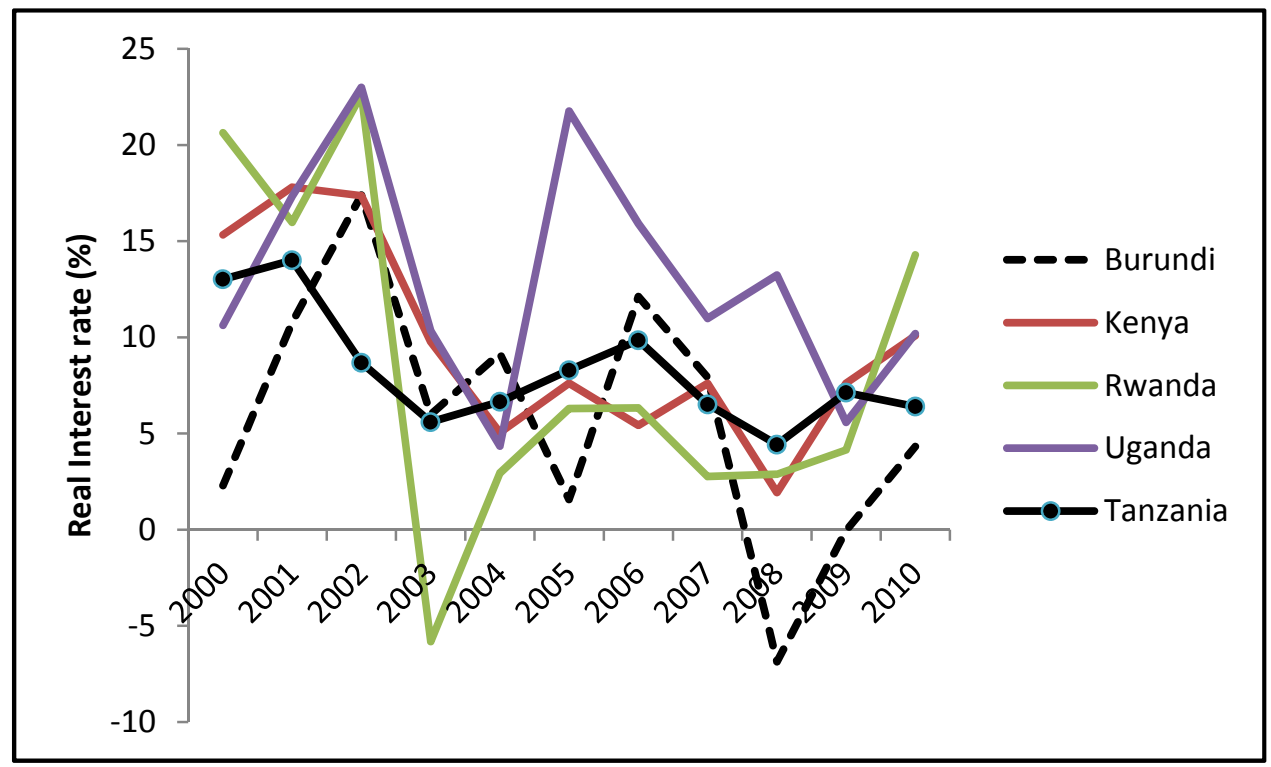

Figure 7. Trends in Real interest rate for EAC countries 2000-2010

Source: WDI database, 2012

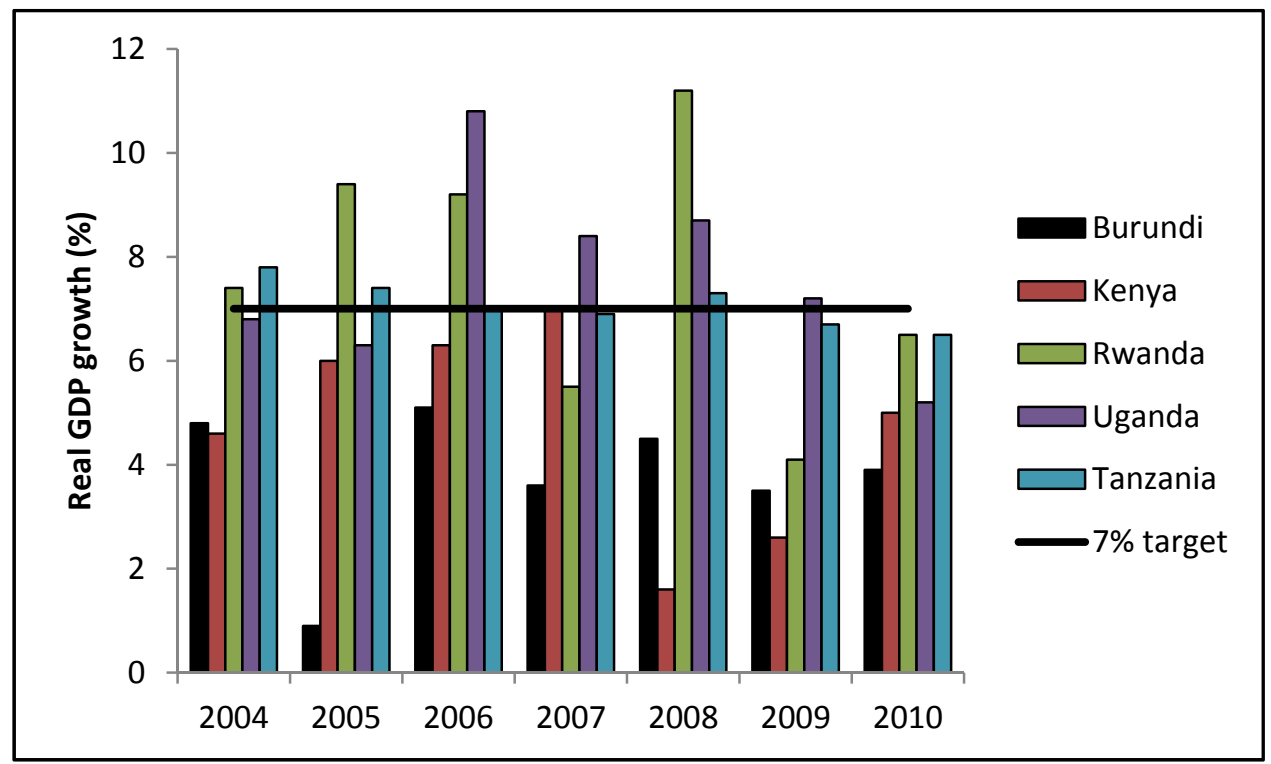

Figure 8. Trends in real GDP growth for EAC states 2004-2010

Source: IMF African Department database and World Economic Outlook, 2011

GDP growth within and between most of the EAC countries has widely varied over the years except in Tanzania which has had a relatively stable growth of close to 7\% per year. From the 2007 to 2009 Uganda performed best while Kenya and Burundi least considering the criteria of not less than $7 \%$ growth in GDP. Countries have experienced low growth in GDP between in the last two years due to global economic meltdown. A wide range of underlying growth rates points to the straining of shared monetary and exchange rate policy and may cause difficulties for a common fiscal policy in the MU. 


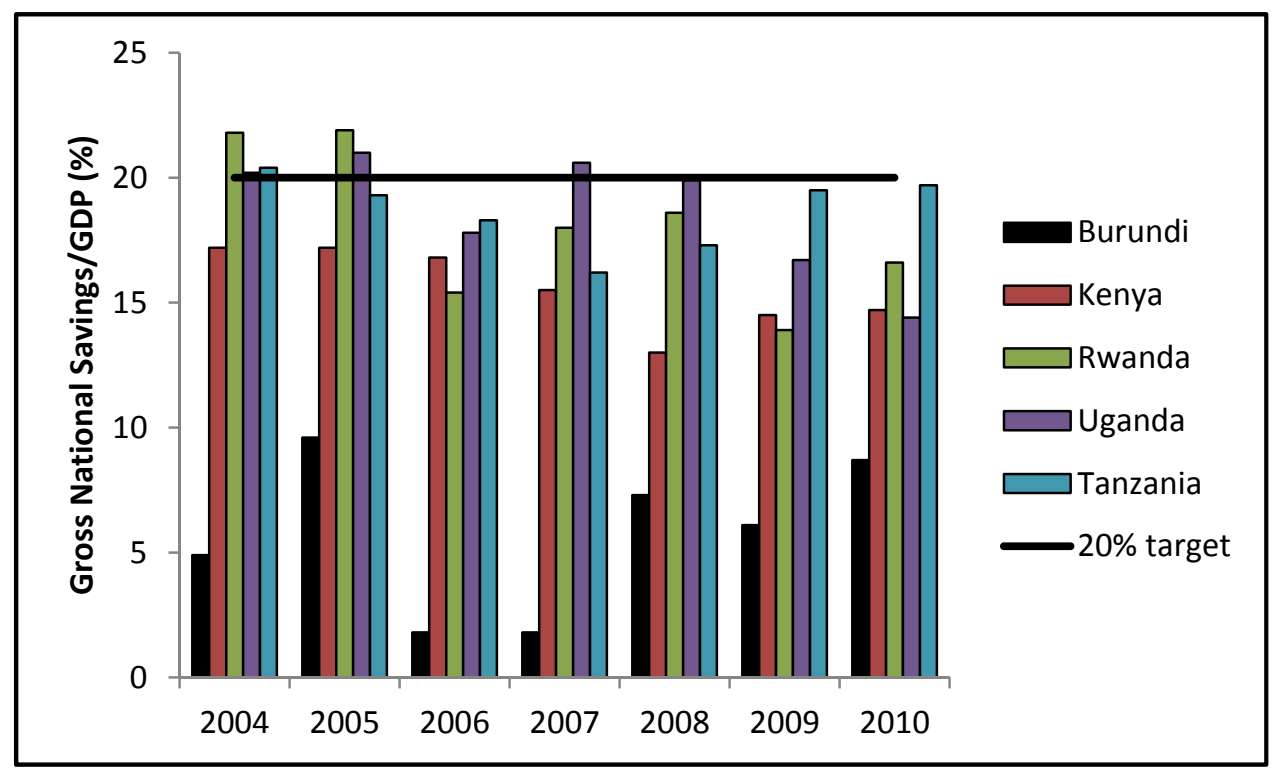

Figure 9. Gross National Savings /GDP for EAC countries

Source: IMF African Department database and World Economic Outlook, 2011

EAC partner states have also found it difficult to achieve $20 \%$ target proportion of national savings to GDP as seen figure 9. Findings reveal that Uganda which did well in 2007 and 2008 fell short in 2009 and 2010 possibly due to the global melt down. The circumstances are the reverse for Tanzania. Burundi remains far below half of this requirement. National savings to GDP ratio is meant encourage fiscal discipline and reduce risk of in the EAMU where by member countries with lower savings take funds from other countries with higher savings. The wide disparities in the rates of savings between countries, presents a highly dangerous situation.

The pursuit of debt sustainability amongst the EAC countries is not well assessed amongst studies the reason being that the criterion is not well defined. There are questions as to what measure to use, possibly the use of gross public debt or the total national debt to GDP ratio could prove most appropriate in these regards. IMF (2011a) considered the use the former and established that countries had made significant progress since 2006 by keeping the gross public debt below $50 \%$ of GDP with Uganda and Rwanda out performing others by having just half of that proportion. The challenge is thrust towards Kenya and Burundi not to take higher debts that would exceed the $50 \%$. However there are also concerns of managing the current gains against debt in all other countries given that they are rapidly taking on more debt after the recent debt relief.

Progress towards currents accounts deficit reduction remains very slow and mixed. While some partner countries shown declining trends others have had increasing trends. For most members current accounts deficits represent a very small part of GDP not greater than $15 \%$. For others like Burundi current account deficits are a big part of GDP in the proportion of over one third of GDP. This work was unable to find any information relating to the progress of the 25 core principles of bank supervision or an agreed action plan for harmonization of bank supervisions. Nonetheless, there is some evidence tied to the pursuit of regional financial integration has seen the full liberalization of capital transactions in the region for Uganda, Kenya and Burundi. There has gradual removal of restrictions on intra-regional capital transactions and the harmonization of market infrastructure resulting the formulation of the cross-border listing. A range of other programs that could transform the regional financial market including the fields of tax, financial reporting and education, and trading systems are in the pipeline (EAC, 2009). Yet these are only enablers that create an appropriate environment for financial transactions, tangible evidence concerning the EAC financial market integration ought to be established.

\subsection{Macro-economic Convergence}

While the above tendencies illuminate on the economic progress countries have made towards the MU, they are unable to validate with confidence the possibilities of forming same. Knowledge of such potentialities of an MU or single currency area is best revealed by rigorous analysis of linkages, dispersion and convergence of the economies of the key macroeconomic indicators. Correspondingly EAC member countries must be able to demonstrate this characteristic prior to the union. 
The viability of monetary unions is best assessed using the optimal currency area (OCA) theories (Mundell, 1961). Proponents of these theories argue that potential MUs should exhibit similarity in economic structure characterized by high degree of wage flexibility to allow for the adjustment of asymmetric shocks; a high degree of labor mobility; and a high degree of goods and market integration across States. The size and openness of the economy, degree of commodity diversification and fiscal integration are also important to the formation of a successful MU (Mckinnon, 1963; Kenen, 1969; Flemming, 1971). Furthermore, the similarity in policies and desire for a political union are additional key factors (Haberler, 1970; Cohen, 1993).

The theories have been used to determine probable monetary unions by focusing on real and nominal convergence (Opolot and Lavunda, 2009; Marelli and Signorelli, 2010; Smaghi, 2007). Real convergence relates to the equalization of economic welfare and social structure. In this case, similarities in the level of competitiveness, labor and macroeconomic performance as measured by real economic outcomes of per capita incomes, productivity, industrial indicators, trade links, business cycle synchronization etc. reveal the extent real convergence. On the other hand nominal convergence relates more to the movement of nominal variables including budget deficits, inflation, exchange rates etc.) directed to the achievement of macroeconomic stability and greater uniformity. Under this, is also the realization of institutional convergence whose focus is on the harmonization of institutional policies and legislation.

A variety of econometric techniques have been used to determine the presence of these economic behaviors across regional economies. Those encountered within the context of EAC have included the use of sigma convergence, unit root tests, generalized purchasing power parity and vector auto regression whose basis is cointegration analysis. Often these methods demand high frequency data sets which are not always available especially since the EAC is a recent occurrence. Nonetheless studies have mainly made use of time series data extending from 1981 to 2010. Both real and nominal convergences have been investigated using variables defined by the macro-convergence criteria.

In assessing real convergence research has paid more attention to real GDP growth. In a bid to establish if the EAC is a viable MU, Buigut and Valev (2005) investigated to symmetric nature of demand and supply shocks belying real GDP growth in partner states from 1980-2001. Theory asserts that partner countries within a monetary union should have monetary policies similar to that of the monetary union as whole and thus cannot apply monetary and exchange rate policies to respond to country specific shocks (Mundell, 1961; McKinnon, 1963). Results from this study showed that short run shocks were not symmetric, but lagged supply shocks associated with trade patterns were. In addition the speed of adjustment to shocks and the effect of variability on real output (real GDP) also appeared to be symmetric with the exception of Uganda. In particular Uganda experienced large shocks and adjustments were very slow which could prove costly in a monetary union. Although the findings could not confirm a viable monetary union at the time, they pointed towards a potential MU if there is deeper trade integration emphasizing the importance of well-functioning common market. This study utilized data ending just the time of EAC, but outcomes involving use of recent data sets have not been that different. In particular Opolot and Osoro (2009) who examine the synchronization of business cycles of real GDP from 1981 to 2007 across the region find peculiar differences. While business cycle co movements across the region have improved since the 1990's, they are still very low. Only Tanzania and Uganda have optimistic synchronizations within the region casting more doubt on assuming the monetary union at the moment. Opolot and Lavunda, (2009) take a different approach. Using panel unit tests on the same data, the researchers established that there was convergence of real GDP growth in region but this consistently being generated by Rwanda and Burundi. The 3 original countries showed divergence with Tanzania consistently showing a drift from the region. Further assessments of catch-up growth have conducted based on per capita real GDP (Note 3) Sigma tests carried out by IMF (2011) indicate that with the exception of Burundi, incomes across the region have grown closer over the last 15 years (1996-2010). All other countries' per capita incomes appear to be catching up Kenya. Findings by Opolot and Lavunda, (2009) further confirm this, but add Burundi to the group of 4. This dissimilarity in result could be explained by differences in data sample and might imply that in the recent years all other economies have grown much faster and there institutional structures and policies have become more similar compared to Burundi.

In regards to the nominal variables, investigations have mostly turned to exchange rate behavior. Mkenda (2001) examined the convergence of real exchange rates of Tanzania, Uganda and Kenya, generalized purchasing power parity. Findings revealed some co-integration, but remained short of confirming a single currency area. Most recently Falagiada, (2011) studied the behavior of nominal exchange rates all five countries and uncovered some degree of economic integration. However the findings were unsatisfactory about convergence in all 5 counties. Buigut (2011) adds to these efforts by looking at both nominal and real exchange rates regions using data from 
1991 to 2009. He finds partial convergence due to that fact that some countries exhibited show convergence in the short run. He is unable to find a common trend in long run for these EAC countries urging caution for taking on an MU.

Largely studies have found no evidence of budget deficits (including and excluding grants) convergence in the region in the region (IMF, 2011; Opolot and Lavunda, (2009). Analyses of the evolution of the criteria have instead shown increasing patterns of dispersion and divergence across states. Findings concerning inflation rates convergence appear to be mixed. While some found divergence across states (IMF, 2011), others discovered convergence (Kishor and Ssozi, 2010; Opolot and Lavunda 2009). Even so in later case, the effect attributed more to the three original countries Tanzania, Uganda and Kenya. Upon isolation from trio, Rwanda and Burundi appear to exhibit inflation divergence. Yet others Buguit (2011) have found partial convergence. In general, there is very little research on the convergence of current account deficits and national savings. At this moment we rely only on results by Opolot and Lavunda (2009) who appear to have picked interest in the variables. Their panel unit root tests show convergence of the current accounts and national savings of the group of 5. However a more detailed examination reveals that affects appear to be attributed to Kenya, Burundi and Rwanda in the case of current accounts deficits. While for the case of national savings convergence is mostly attributed to Kenya and Rwanda. These findings are quite surprising given that Rwanda and Burundi have just recently emerged out of civil strife compared to Uganda or Tanzania. In addition it should not be forgotten that data range used is for earliest period of the EAC as a five block.

The above results provide us with empirical evidence on the state of macro-economic convergence in the five EAC partner countries. Findings indicate partial convergence of some countries to some criteria, but generally the economies remain unaligned to these benchmarks pausing risk for the establishment of an MU. These dissimilarities further suggest that countries largely follow independent policies and ought to make significant adjustments in of support the monetary policies to make union more credible.

\section{Challenges in Meeting the Convergence Criteria and Possible Strategies}

The above findings indicate that macroeconomic convergence for EAC partner states has been very slow. Fast tracking the MU to the 2015 deadline faces great risk since countries are still struggling with fulfilling current criteria which tighten over time. Based on the experiences of other countries and monetary unions, IMF (2011a) and ECB (2010) have put forth several proposals embedded in foreseen challenges. According to IMF (2011a), the indicators were considered to be too many. The presence of secondary criteria were deemed unnecessary given that they were derived from the primary criteria and do related more to economic performance that advancement towards the MU. Aspects such as the 7\% real GDP growth, 20\% national savings/GDP ratio exchange rate stability and debt sustainability relate more to national economic growth goals. The 25 banking principles pertain more to institutional reforms that could be placed in a separate program. Placing these in a separate program would increase focus on attaining the much needed benchmarks which are the primary criteria.

In regards to budget deficits, the difference between that deficit including grants and that excluding grants was considered too constrictive at 3\% of GDP restraining the use fiscal policy especially in use of donor funding for any country. For countries not exceed the higher limit on deficit, budget spending including donor grants must be set within lower limit which would allow for excess spending of donor money over $3 \%$. However, most countries receive over 3\% of GDP in donor funds will always choose within the narrow criteria thus reducing on the relevancy of cap of budget deficits excluding grants. There were also concerns of achieving deficit target of $2 \%$ since most countries have never achieved the mark other than Rwanda. A level of $2 \frac{1}{2} \%$ was suggested given that its consistency with the debt to GDP ratios and GDP growth of 7\%. Yet framework should allow for lifting of the ceiling that in periods of large economic shocks to facilitate counter cyclical fiscal response during economic downturn as experienced in 2009. Partner states were urged that adopt measures exclude temporary incomes and incomes from natural resources from deficits to facilitate scaling fiscal sustainability. Temporary income funds can be misleading about the underlying fiscal performance given that increase volatility and strengthen deficits including grants.

A foreseeable difficulty is that of partner countries being unable to meet the 2011-2014 reserve targets of 6months of imports. Except for Uganda, all other countries came short of the mark throughout the stage I period. While higher reserves lower risks at onset of the single currency, attaining the 6 month requirement would necessitate countries tighten fiscal and monetary policy against economic growth. That is countries would have to reduce on fiscal spending to direct the related resources to savings. Also the central bank could purchase foreign currency to neutralizing the creation from bonds constraining credit growth. Assuming that the requirement may be lower upon acceding the MU then a more achievable level of 4.5 may be appropriate. 
The current Inflation rate benchmark is also considered too taxing given that none of nations have achieved it in the past even when the effects from food and fuels prices are dealt with. Revising target to a reasonable level that can be adhered to by nations is perhaps more favorable to the process as long as it does not compromise on achieving and maintaining price stability by countries. A level of $8 \%$ was proposed since it bring most countries closer to fulfilling inflation convergence. Yet this does not have to been uniform. For countries that have succeeded in the past in meeting the 5\% maintaining the present level for successful at lower levl would reduce on possible risks of inflation indiscipline and distortions of regional competiveness due to large differences in inflation. Another alternative is to adopt a variable ceiling of 3 points above average of the best performing countries which means that this must be $7 \%$ to be consistent with evidence of not more than $10 \%$. There is a need to for all countries to report the core inflation and harmonize the mechanisms used to arrive at the measure.

As mentioned earlier studies emphasized lack of ERM for all countries that is paramount to the tracking of bilateral exchange rate stability. It is important that an appropriate ERM be adopted and be considerate of the EAC's choice of exchange rate regime for a single currency. Furthermore it should specify the extent of currency flexibility with a reflection of transition from constricted to wide-range fluctuations.

Progress towards the MU was also constrained by lack of quality information of specific indicators which in-turn limited their monitoring and assessment macro-economic performance. In some cases data is collected, other cases not. Possibly the most outstanding issue is that countries use different variables say when determining particular criteria such as the budget deficit. The lack of a harmonized way and transparency in collecting relevant data has serious consequences when evaluating convergence.

It was noted that convergence efforts were further hampered by the lack of a surveillance system or institution to enforce fiscal discipline and ensure adherence to the criteria. Setting up a mechanism would make it possible to identify destabilizing trends, contribute to broad-based macro-economic stability through checks on fiscal imbalances, debt managements and formulation of appropriate policy responses.

Furthermore, the issue multiple member ship of EAC partner states still lingers and could derail the convergence process. In this regards, Tanzania is a member of SADC while Uganda and Kenya are part of the COMESA both of which considering monetary unions and have put forward convergence criteria with bench marks that are in some instances conflicting. For example and as mentioned earlier while EAC criteria demand fixed budget deficits SADC offers flexible routines. In addition SADC has limits on debt accumulation of up to $60 \%$ a trend that is not associated with the EAC. Furthermore COMESA demands adherence to additional criteria linked to the central bank financing, liberalization of capital accounts, and limits to generation of domestic revenue not considered by the EAC. While all RECs are simultaneously undergoing convergence, there are differences in scheduling of targets. EAC has proposed to attain full convergence by 2015. But the COMESA and SADC assume to get there by 2018. Harmonizing the criteria of the three blocks in a manner whereby the outcome pauses no risk to any partner was considered important in enhancing convergence efforts.

Lastly, the current state of the common market on whose basis the monetary union is hinged upon begs for a more cautious process and by itself is a challenge to achieving convergence. As theory and empirical evidence have suggested, deeper trade integration will be great enabler to the convergence process in the region. On one hand the removal of trade barriers may bring about correlated business cycles due to common demand shocks and intra trade, on the other hand integration will promote industrial specialization and inter-trade causing more synchronized output fluctuations. This could be rather slow in the case of EAC. This is because countries are not fully dedicated to implementing the customs union and common market protocol were signed to benefit trade across the region. This lack of commitment is linked to the fear of loss of revenue. Even if countries were to fully able to take on these procedures, the wide spread nature of non-tariff barriers (NTBs), poor road infrastructure and other problems cause substantial disparities in the conduct of business between countries and trounces the idea of free trade (Note 4).

\section{Conclusions and Policy Implications}

Clearly the path to the EAMU is a difficult one. Both emerging trends and detailed empirical analysis generally indicate that EAC economies are far from achieving macro-economic convergence based on the staged indicators. Findings show that criteria appear to be set high above country economic performances making them trying to attain but also point to a lack of commitment to the process on the side of the countries. Revising the proposed bench marks to reflect this trend and possible economic shocks might be might be one way to go. However the process could be long, and is unlikely to yield quick results given that it requires all countries to come to a common agreement. The uneven convergence where by some countries are progressing faster than others and to some but not all criteria, may suggest that nations adopt a path similar to that EU states or west 
African member states where by states concentrated on fulfilling certain criteria and countries whose economies are aligned to such criteria could form monetary union to which the members can later join upon meeting convergence.

Regardless of the situation and nature of outcome, EAC economies must aggressively pursue policies that promote economic growth that line up with those of the monetary union. Programs that lower and enhance the management of the budget deficits in sustainable way will be vital to enhancing convergence. Reductions in deficits would entail locating and strengthening revenue generating mechanisms to counter fiscal spending. This does not imply that nations reduce spending, but rather generate sufficient amounts of revenues to exceed expenditure. This means that countries must identify and capitalize on the key economic drivers and formulate appropriate plans to stimulate their economic activity and related sectors for sustained economic growth. On a general side the main drivers of growth in the EAC countries are listed as private consumption, exports and gross fixed capital, tourism revenues, foreign investment, services and aid. The common key enabling sectors include agriculture, manufacturing, trade, tourism, and infrastructure. The factors and sectors act interdependently such that enhancing one sector could induce growth in another. The contribution of private consumption to growth is associated with the increasing demand for services in the region. The Kenyan economy has benefited immensely from the sale of consumption goods such as ICT, Uganda and Rwanda have fallen suit and show no signs of slowing down. The potential to earn export revenues from intra-regional agriculture trade and external trade with countries outside the block as wells as tourism remains unexhausted. While EAC economies have prioritized improvement agriculture and related trade, quality investment in terms production and trade infrastructure remains low and the export base is still narrow for most countries. It is important that countries formulate policies that encourage economic upgrading in these sectors and increase export diversification which in turn will result in a boost in revenues.

EAC countries are still developing and thus good grounds for foreign direct investment especially in industry and manufacturing and transportation. However region's ability to attract sufficient levels FDI is remains weak. The incapability to draw in FDIs has denied the region the much the needed capitals for investment especially that partner countries are characterized by low incomes and savings. Furthermore extra advantages of employment, managerial skills and technology that add to growth and development are lost. Within the EAC, FDI inflows have been linked to the local size of market and natural resource development in areas of mining and oil extraction, some agriculture and most recently to services. However, such invests are thin provide little strength to the fiscal balance. Thus economies must ascertain other FDI opportunities related to additional factors such as geographical location, infrastructure and the stock of human capital. Along with this is the relevant policy to create and maintain good environment and investment climate to draw in FDI. While countries have improved in political and macroeconomic stability and reduced tariffs to trade, a lot remains to be achieved on the side of supporting institutions and physical and social infrastructure in terms of quantity and quality of roads and communication systems, skilled labor to allow the efficient delivery public services imperative for thriving of FDI.

Countries and the region must also be able deal the constraints surrounding the common market. In addition to rectifying problems in various individual country economic sectors and institute will improve on the functioning of the market, combining efforts to harmonize policies and completely eliminate NTBs will have far greater impacts on enhancing profound regional integration and strengthen the chances of achieving a successful MU.

Further attention must be paid to building capacities in data collection, harmonization and sharing of all relevant statistics to facilitate the monitoring process. At the moment the MAC committee involved in undertaking various activities associated with the monetary union acknowledges the strengthening of knowledge, skills, attitudes and competencies of central bank officials as critical to monetary convergence. There also the lack of capacity in information technology, absence of knowledge sharing infrastructure and staff retention that must be addressed. In addition it also necessary to engage in awareness campaigns for all stakeholders regularly to improve legitimacy of the union.

\section{References}

Alesina, A., \& Barro R. (2002). Currency unions. Quarterly Journal of Economics 117(2), 409-436. http://dx.doi.org/10.1162/003355302753650283

Bean, C. (1992). Economic and monetary union in Europe. Journal of Economic Perspectives, 6(4), 31-52. http://dx.doi.org/10.1257/jep.6.4.31

Buigut, S. (2011). A fast-track East African Community monetary union? Convergence evidence from a cointegration analysis. International Journal of Economics and Finance, 3(1), 255-265. 
Buigut, S.K., \& Valev N.T. (2005). Is the proposed East African monetary union an optimal currency area? A structural Vector Autoregression Analysis. World Development 33(12), 2119-2133. http://dx.doi.org/10.1016/j.worlddev.2005.06.006

Calmfors, L. (2001). Unemployment, labor market reform, and monetary union. Journal of Labor Economics, 19(2), 265-289. http://dx.doi.org/10.1086/319561

East African Community (EAC). (2007). Treaty for the establishment of the East African Community. (As amended on 14th December, 2006 and 20th August, 2007). http://www.eac.int/index.php/advisory-opinions/doc_details/158-amended-treaty-for-the-establishment-of-e ast-african-community.html

. (2009). EAC Monetary Affairs Committee: Achievements, challenges and way forward-(1998-2008). http://www.eac.int/index.php/advisory-opinions/cat_view/42-about-eac.html.

(2011). EAC Development Strategy (2011/12 - 2015/16): Deepening and accelerating integration. http://www.eac.int/index.php/advisory-opinions/doc_details/650-4th-eac-development-strategy.html

European Central Bank (ECB). (2010). Study on the establishment of a monetary union among the partner states of the East African Community. ECB Staff Study.

Falagiarda, M. (2010). Are the East African countries ready for a monetary union? Traditional Indicators and Cointegration Analysis. JEL Classification, E42, F33.

International Monetary Fund (IMF). (2011a). Managing the macroeconomic convergence process ahead of the monetary union. A consultancy Report

(2011b). World Economic and Financial Surveys. Regional Economic Outlook. Sub-Saharan Africa recovery and new risks. Washington DC.

Kenen, P. B. (1969). The Theory of Optimum Currency Areas: An Eclectic View. In Mundell R. and Swoboda A. Monetary Problems in the International Economy.

Kishor, N. K. \& Ssozi, J. (2009). Is the East African Community an optimum currency area? JEL classifications: F33; E32; F15; N17. Retrieved from http://mpra.ub.uni-muenchen.de/17645/1/MPRA_paper_17645.pdf

McKinnon, R. I. (1963). Optimum Currency Areas. American Economic Review, 53(4), 717-725. Retrieved from http://www.jstor.org/stable/1811021

Mkenda, B.K. (2001). Is East Africa an optimum currency area? Working papers in economics Goteborg University, (41), JEL-Codes: C32; F15; O55. Retrieved from https://gupea.ub.gu.se/handle/2077/2675

Mundell, R. A. (1961). A theory of optimum currency areas. American Economic Review, 51(4), 657-665. Retrieved from http://www.jstor.org/stable/1812792

Opolot, J., \& Osoro, N. (2009). Is the East African Community suitable for a monetary union? An enquiry of Idiosyncrasies and Synchronization of Business Cycles, Bank of Uganda Staff papers, 1(3),118-140, http://www.bou.or.ug/export/sites/default/bou/bou-downloads/research/Staff_Papers/Vols/All/Bank_of_Uga nda_Staff_Papers_Vol_3_Num_1_2009.pdf

Opolot, J., \& Luvanda, E. (2009). Macroeconomic Convergence in the East African Community: Progress and Implications for the Proposed Union, Bank of Uganda Staff papers, 1(3),53-79. Retrived from http://www.bou.or.ug/export/sites/default/bou/bou-downloads/research/Staff_Papers/Vols/All/Bank_of_Uga nda_Staff_Papers_Vol_3_Num_1_2009.pdf

Schuberth, H., \& Wehinger, G.D. (1998). Costs of European Monetary Union: Evidence of Monetary and Fiscal Policy Effectiveness. European Regional Science Association Conference papers No ersa98p459. Retrieved from http://www-sre.wu-wien.ac.at/ersa/ersaconf s/ersa98/papers/459.pdf

\section{Notes}

Note 1 . This includes water bodies. The surface area excluding water bodies is approximately 1.72 million square kilo meters.

Note 2. SADC and the EU have set the limit of fiscal debt up $60 \%$ of GDP, while the UEMOA has a limit of to $70 \%$ of GDP for member countries.

Note 3. While convergence of per capita real GDP is not characterized as the macro-economic convergence, it is linked to institutional and policy alignment in the countries which is important for economic convergence and successful monetary unions. 
Note 4. The EAC development strategy outlines several challenges that obstruct the realization of gains from the common market including inadequate institutional, national and regional level capacities to domesticate regional policies and information access; low levels of awareness across Partner States; inappropriate legal and regulatory frameworks, continued nationalistic tendencies, weak private sector, differences in education systems, cultural diversities, language barriers, differences in level of economic development including limited participation of the various stakeholders; weak capacities of implementing agencies; inadequate safeguard measures and dispute settlement mechanisms; incomplete harmonization of examination and certification; inappropriate labor policies and legislation; weak urban planning policies and disparities in intra-regional trade (EAC, 2011). 